\title{
The Tragedy of Billy Sunday: The Allure of Populism and the Peril of Anachronism
}

\section{RANDALL BALMER}

FEW FIGURES on the American religious landscape are more colorful than William Ashley "Billy" Sunday, a man whose life was inextricably tied to Iowa. Born in Story County in 1862, Sunday's father was killed in the Civil War, and financial stringency forced his mother to turn the ten-year-old Billy and his older brother over to the Soldiers' Orphans Home in Glenwood in 1872. Eighteen months later, when the state decided to close two of its three orphanages, the Sunday brothers were shipped across the state to the sole remaining orphanage in Davenport, where they remained until 1876 . Billy Sunday worked as a farmhand for several years before moving on to Marshalltown, where he joined the local baseball team, enlisted with the fire brigade, and hired on in a local furniture store, which doubled as a mortuary.

In 1883 Sunday signed a baseball contract with the Chicago White Stockings (his manager, Adrian "Cap" Anson, also from Marshalltown, remarked that Sunday "could run the bases like a frightened deer"). Following a religious conversion at the $\mathrm{Pa}-$ cific Garden Mission in 1886 and shortly after a trade to the Pittsburgh Pirates and a stint as an advance man for revivalist J. Wilbur Chapman, Sunday returned to Iowa as an itinerant evangelist. On January 7, 1896, Sunday conducted his first revival at the opera house in Garner and then began barnstorming throughout Iowa and the Midwest at the turn of the century before launching his campaigns in larger cities. But the flamboyant evangelist did not always meet with success on what he would later call the "Kerosene Circuit." After a rather unavailing visit to Eddyville, for instance, Sunday allowed that the "most low, God-forsaken town he was ever in was Eddyville, Iowa, and Morehead [sic], Minn." and that Eddyville had a "club of infidels of 300." (Sunday's sentiments provoked a spirited response from the editor of the Eddyville Tribune, who asserted 
that in Eddyville "the actual infidels to God, as we understand the term, do not exceed five." ${ }^{6}$

Billy Sunday, then, left Iowa for the big city twice in his life: first in 1883 when he tried out and later signed with the White Stockings and, second, when he forsook the "Kerosene Circuit" for the allure - and the challenge - of urban evangelism. In the course of both of these transitions from rural to urban, from small towns to cities, Sunday characterized himself as something of a bumpkin. Consider, for example, his recollection of being introduced to those who would become his teammates on the White Stockings: "My hair was long, and I sure looked like the hayseed that I was, compared to those well-groomed men, members of that famous old team. ${ }^{\prime 7}$ When he became an urban evangelist at the turn of the century, his self-appraisal was ostensibly the same, but the attitude this time was defiant rather than apologetic. Sunday took pride in the folksy colloquialisms that peppered his speech, and he would often rail against the affectations of the intellectual, urban elite.

As Robert F. Martin argues in his perceptive essay, "Billy Sunday and the Mystique of the Middle West," Sunday's appeal lay precisely in his willingness to characterize himself as a midwesterner, to play up his rural roots and at the same time to puncture the pretensions of the powerful. This self-caricature, Martin argues, held special appeal for turn-of-the-century Americans shaken by the transition from a rural to an urbanized culture. Sunday's words, his appearance, and his rhetoric, laced with country aphorisms and admonitions to old-fashioned morality, resonated with Americans nostalgic for the "good old days" back on the farm. He was, as Martin argues, "a kind of latter-day Lincoln, a strong, vigorous, self-made, egalitarian hero, who came out of the prairies of the Midwest to summon the nation back to its highest ideals."

The image of the farm-state orphan shuffling down the alleys of Chicago calls to mind Benjamin Franklin strolling the streets of Paris in a coonskin hat. Both images, however, are disingenuous. The intellectually agile Franklin easily matched

6. Quoted in Frank D. Brown, Tales of Old Eddyville (Eddyville, 1967), 35, 36.

7. Quoted in Dorsett, Billy Sunday, 19. 
wits with his Parisian hosts, in spite of his desultory attempts to disparage himself as a colonial. So, too, as Martin points out (and as Douglas Frank has argued before him), Sunday was a master entertainer, businessman, and strategist, all of which belied his considerable efforts to portray himself as a rube. ${ }^{8}$ Sunday was, in short, a consummate actor who succeeded in convincing his audiences that he was something other than what he was: a superb showman with an uncanny knack for business. His deceit was by no means as perfidious as that perpetrated by other evangelists (especially the televangelists of the 1980s); it was probably harmless, for the most part, but it was thorough and effective nonetheless. (One wonders, however, if at some level Sunday's appeal derived in part from his own insecurities. He may well have felt inferior and something of an alien in the urban context. If so, his audiences may have sensed his misgivings and identified with them, thereby rendering the evangelist all the more compelling. Whatever the case, Sunday played it brilliantly.)

Martin's argument that Sunday somehow captured the spirit of the age, albeit briefly, also places the farm-state preacher in a long and venerable tradition of American evangelists who intuitively understood their audiences (in the broadest sense of that term). Richard L. Bushman, for instance, has argued that Jonathan Edwards embodied the tensions of his age; the rapid territorial expansion of the mid-eighteenth century, the growth in population, and the increase in commerce all opened new horizons of opportunity but also induced guilt in those who aspired to wealth, thereby making them susceptible to Edwards's revival of seventeenth-century Puritan morality. ${ }^{9}$ George Whitefield, a contemporary of Edwards, used his training in the London theater to extraordinary advantage in a culture with, at that time, no theatrical tradition. ${ }^{10}$ Charles Grandison Finney, of

8. See Douglas Frank, Less than Conquerors: How Evangelicals Entered the Twentieth Century (Grand Rapids, MI, 1986).

9. Richard L. Bushman, "Jonathan Edwards as Great Man," Soundings: An Interdisciplinary Journal 52 (1969), 15-46.

10. Harry S. Stout, The Divine Dramatist: George Whitefield and the Rise of Modern Evangelicalism (Grand Rapids, MI, 1991). 
Rochester, New York, understood the spirit of his era as did no other evangelist in American history. Finney assured people who had only recently taken their political destiny into their own hands that they could now determine their religious destinies as well. ${ }^{11}$ Other evangelists, both before and after Sunday, also were uncannily attuned to the possibilities and the anxieties of the age in which they lived. Dwight Lyman Moody and T. DeWitt Talmage understood the challenges of the cities, Charles E. Fuller and Aimee Semple McPherson saw the possibilities of radio in an increasingly transient society, and Billy Graham, with his self-effacing demeanor and his aw-shucks Carolina drawl, nevertheless jumped on the emerging media technologies and the allure of corporate culture in the middle of the twentieth century. Sunday, the savvy evangelist masquerading as a rube, stands firmly in that tradition.

Martin's essay on Billy Sunday also demonstrates that homing in on popular prejudices can be a double-edged sword, especially if the evangelist fails to adjust to changing times. Again, history provides ample precedent. Edwards kept harping on the issue of individual regeneration long after the Great Awakening had fallen out of favor with his congregation in Northampton, Massachusetts; they eventually forced his ouster. Audiences finally tired of Talmage's bombastic sermons in Brooklyn; he stood trial before an ecclesiastical tribunal for "using improper methods for preaching" in 1879, and quietly moved on to Washington, D.C., in 1895 after his Brooklyn Tabernacle burned down for the third time in his twenty-six-year tenure. Perhaps no image captures anachronism better in the twentieth century than an old-fashioned tent revivalist traveling dusty backroads while his more savvy confreres do their preaching from the comfort of an air-conditioned radio studio or television sound stage.

After riding a wave of popularity at the turn of the century with his homespun appeals to piety in the Progressive Era, Sunday found himself sadly out of touch in the 1920s and 1930s. As Martin points out, Americans, who had endured profound

11. Charles E. Hambrick-Stowe, Charles G. Finney and the Spirit of American Evangelicalism (Grand Rapids, MI, 1996). 
demographic changes around the turn of the century, had shed most of their ambivalence about modernity, urbanization, and industrialization by the $1920 \mathrm{~s}$. Most were prepared to embrace the future without looking back to the provincialism that Sunday symbolized. Whereas in the first two decades of the new century Sunday had been a media sensation in such places as Chicago, New York, and other major cities of North America, by the 1920s and 1930s he was relegated to mid-sized and smaller cities, far removed from the centers of power and influence, back almost to the "Kerosene Circuit."

"The big cities scare me," Sunday confided to his wife in 1920. It was a remarkable confession coming from someone whose early career was marked by such bombast and bravado, someone whose homespun rhetoric and hayseed demeanor had taken urban America by storm. By 1920, the man who had risen to prominence by speaking the language of populism had himself become an anachronism by failing to adapt to the changing culture. The man who had started life on the margins - an orphan reared in Iowa - and who had insinuated himself into the corridors of influence at the zenith of his career found himself at the margins once again at the twilight of his career. Tapping into the spirit of the age, as Sunday learned, is always an inexact science. Success can be euphoric, but it is almost always fleeting. Therein lies the tragedy of Billy Sunday. 
Copyright of Annals of Iowa is the property of State of Iowa, by \& through the State Historical Society of Iowa and its content may not be copied or emailed to multiple sites or posted to a listserv without the copyright holder's express written permission. However, users may print, download, or email articles for individual use. 